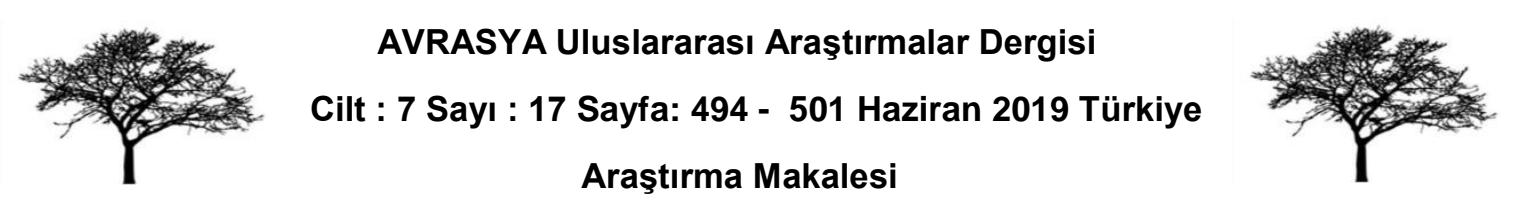

\title{
DISIDENTIFICATION AND HOMELESSNESS IN TABISH KHAIR'S NIGHT OF HAPPINESS
}

Mustafa BÜYÜKGEBiZ*

\begin{abstract}
Tabish Khair, who is an Indian author settled in Denmark, employs a postcolonial discourse in his works. He creates multicultural and also anti-colonial fiction by blending his native culture with the adopted western one. Tabish Khair's novels, in particular, resist the hegemonic voice of the Western culture and as an author, he tries to reflect the original voice of postcolonial characters by focusing on their cultural clashes and discontents which emerge when these characters live in the West as immigrants or interact with the colonial culture. One of the most striking novels in which he portrays vivid characters with identity crisis is his latest novel; Night of Happiness. The novel, named after an important date for Muslims known as Shab-e-baraat night, was first published in 2018, and narrates the story of postcolonial characters who suffers from identity loss in the postcolonial, ambivalent atmosphere of contemporary India. In this sense, the aim of this article is to unfold the psychological and social defects of formerly colonized individuals in our contemporary era by referring to some specific quotations from the novel, and to apply Postcolonial Literary Theory to shed light on the novel's anti-colonial discourse, and Khair's humorous style of social criticism.
\end{abstract}

Keywords: identity, crisis, postcolonialism, ambivalence.

\section{TABISH KHAIR'IN MUTLULUK GECESI ROMANINDA KIMLIKSIZLEŞME VE YERSIZLIK}

\section{öz}

Danimarka'da yaşayan Hint yazar Tabish Khair, eserlerinde sömürgecilik sonrası anlatıma yer verir. Kendi öz kültürünü ve sonradan edindiği Batı kültürünü harmanlayarak çok kültürlü ve aynı zamanda sömürgecilik karşıtı bir kurgu yaratır. Tabish Khair'in romanları sıklıkla Batı kültürünün baskıcı sesine direnir ve bir yazar olarak kendisi, Batı'da göçmen olarak yaşadıklarında ya da sömürgeci kültürle etkileşime girdiklerinde ortaya çıkan kültürel şokları ve hoşnutsuzluklarına yoğunlaşarak, sömürge sonrası dönem karakterlerinin gerçek seslerini yansıtmaya çalışır. Kimlik karmaşası yaşayan keskin karakterler yarattığı, en çarpıcı romanlarından biri de son eseri Night of Happiness'tır. Müslümanlar için önemli tarihlerden biri olan Berat Kandili gecesinden ismini alan roman ilk 2018 yılında basılmıştır ve günümüz Hindistan'ının sömürge sonrası ve karmaşık atmosferinde eski sömürge karakterlerin hikayelerini anlatır. Bu bağlamda, bu çalışmanın amacı romandan belirli alıntılara değinerek

* Alanya Alaaddin Keykubat Üniversitesi Yabancı Diller Yüksekokulu, mustafa.buyukgebiz@alanya.edu.tr, Orcıd ID: 0000-0003-1911-1766 
günümüzdeki eski sömürge bireylerin psikolojik ve toplumsal bozukluklarını açığa çıkarmak, ve romanın sömürge karşıtı anlatımına ve Khair'in mizahi toplumsal eleştiri tarzına ışık tutmak amacıyla Sömürgecilik Sonrası Dönem Edebiyat Kuramı'nı esere uygulamaktır.

Anahtar Kelimeler: kimlik, kriz, sömürge sonrası, kararsızık

Tabish Khair is an Indian author settled in Denmark and currently works as a scholar in the Department of English at Aarhus University. Although he lives in Denmark, his works -both fiction and non-fiction- are in English.

Both in his poetry and prose works, Khair mainly focuses on some of the widely debated tenets of Postcolonial Literary Theory such as otherness, identity and discontent in colonized cultures. In this respect, he may be accepted as a postcolonial writer. Particularly in his novels, he portrays sharp and clear characters who suffer from disorientation in Western culture and problem of otherness as colonized subjects. In this sense, his novels provide a perfect basis to analyse and understand the psychology of the colonized immigrants and their discontent.

Night of Happiness is Tabish Khair's latest novel, published in 2018 and the story is set in the beginning of 2000s. Just like Khair's earlier novel The Thing about Thugs, the main source of the narration is, once again, some manuscripts found by the narrator in somewhere irrelevant. This time, the reader is informed in the beginning of the novel that the manuscript, which tells the story of the novel, is found in a drawer of a 5-star hotel room. The manuscript is written by Anil Mehrotra, a successful but shallow Hindu businessman, who tells the story of himself and one of his employees, Ahmed.

Mehrotra begins to narrate the story in a Shab-e-baraat night, which is an important night celebrated annually in Muslim communities. It is revealed early in the novel that Shab-e-baraat means 'night of salvation' or 'night of happiness' which also gives the novel its name. In a Shab-e-baraat day, Anil Mehrotra works in his office with his 'right-hand man', Ahmed. Mehrotra gives details of Ahmed's background in the company and how he has employed him. Ahmed is a hardworking man who is reliable and able to work late in the office without complaining. His only demand from his employer is that he wants a one-day-leave from work in Shab-e-baraat. Although he knows nothing about this sacred Islamic night, it is not a problem for Mehrotra since Ahmed works more than enough for the rest of the year.

However, this time, he wants Ahmed to work overtime since they have lots of things to do in the office. Ahmed works more than expected that night and the weather was so bad for him to get home in time, so Mehrotra decides to give him a lift. When they reach Ahmed's place, Ahmed invites Mehrotra home to eat traditional halva and Mehrotra accepts the invitation just to be kind. When he enters the apartment, Mehrotra feels something different at home. He does not see Ahmed's wife at home and thinks it is normal because she is a shy Muslim woman. However, he is thrilled with the halva they offer him. The plate is empty, there is no halva at all, but Ahmed pretends to eat it. He grows suspicious of him and his invisible wife. 
The rest of the novel unfolds Mehrotra's suspicions of Ahmed and his struggle to find out the truth about Ahmed's private life. He gets help from a private detective, Devi Prasad, to collect more information about Ahmed and his past, and he begins to question even his own life and identity with his shocking findings about Ahmed and his wife's background. Throughout the novel, identity crisis comes out as a major theme in various aspects, and Khair snipes the source of this crisis by sketching characters from different layers of postcolonial Indian society.

With the departure of British colonial forces in 1947, India gained independence. However, it does not mean that India has completely recovered itself from the defects of colonialism. This political independence and postcolonial awakening could not provide cultural and ideological independence. The imperial effects on the society have still been felt and a contemporary sense of colonization is still active today. Bhabha suggests that 'all post-colonial societies are still subject in one way or another to overt or subtle forms of neo-colonial domination, and independence has not solved this problem' (Bhabha, 1996: 2).

The main outcome of this 'domination' in all postcolonial societies emerges as social and individual identity problems. This problematic issue of identity is common in all formerly colonized societies since these societies are in struggle to rediscover their cultures and form brand new identities for their states. There is not much to talk about identity unless it is in a problematic condition. As Mercer asserts 'identity only becomes an issue when it is in crisis, when something assumed to be fixed, coherent and stable is displaced by the experience of doubt and uncertainty' (Mercer, 1995: 43). The unstable postcolonial atmosphere creates binary oppositions while defining personal and national identities. It is clear that people need 'others' to define themselves which leads to otherness in society, and otherness causes dislocations of identity.

As it is discussed in the previous chapter, colonial and postcolonial dislocations of identity results in what Homi K. Bhabha calls mimicry and hybridity. These problematic postcolonial concepts cause serious psychological disorientations mostly on individuals. In Night of Happiness, Khair successfully creates postcolonial characters who suffer from disorders of identity and sense of belonging. The characters' inconsistent psychology is clearly demonstrated in the novel.

The narrator of the novel, Anil Mehrotra, is one of the best examples of postcolonial, disoriented individual. He is a Hindu businessman who studied in the west, and identifies himself more with the western culture rather than his native one. He does not know much about his country and culture. While he is giving some details about Ahmed's background, he describes Surat, a large city in India with a population of approximately 4.5 million, by saying that 'perhaps, they had missed living in a smaller town- and Surat is a relatively small place in Gujarat' (Khair, 2018: 125).

He has nothing to do with his native Hindu culture. On several pages in the novel, he describes his Hollywood-like life in his house with his family. From his descriptions, the reader understands that Mehrotra family is quite rich with a large residence and several servants. He narrates a typical morning at home and it completely resembles to an opening scene of a Hollywood movie. 
The next morning was clear, azure sky and all sunlight falling through the gaps between the curtains like solid golden bars. By the time I went down, the girls -seven and ten years old- were already in their school dresses and dutifully spooning cornflakes under the watchful eyes of their ayah and the missus (Khair, 2018: 49)

$\mathrm{He}$ also informs the reader that he studied in Columbia University in America. In this sense, Anil Mehrotra represents a perfect example of a mimic man in the novel. As it is mentioned earlier, through education and discourse, the colonizer creates an atmosphere suitable for mimicry. He and Devi Prasad, a private investigator for Ahmed, bring their daughters to play golf at weekends and he expresses that it is a must for them to learn it by saying that 'as our respective wives had decided the kids had to play golf' (Khair, 2018: 54). Khair also sketches these two men as if Americans while their kids are playing golf. Anil says 'so, once a week, we took them to the club, where an instructor put them through their paces, while we reclined, drink in hand, on wicker chairs outside the club restaurant' (Khair, 2018: 54-55). He also confesses that it is not his freewill to do that. $\mathrm{He}$ is, in a way, forced to behave so by saying that 'this was expected of us, as fathers' (Khair, 2018: 55). He is aware of the fact that he cannot behave like a Hindu father there. This ambivalent situation is the first sign of Mehrotra's identity crisis and his lost in perception through the end of the novel.

Not playing any sport but golf is a must since it is a clear representative of western culture and a good tool for mimicry. Just like Amir Ali, who defines western culture as 'God of Reason' in The Thing about Thugs, Anil Mehrotra defines golf as a sensible game. He asserts that 'I told myself golf is a sensible game, golf makes perfect sense' (Khair, 2018: 64). He tries to escape from the realities of his nation since Ahmed destroys his postcolonial illusion by serving him invisible halva, and being 'sensible' and 'reasonable' are crucial for him to stay 'westernized'. He talks about golf as a sensible game, but he is so bad at playing it. He says 'but this time, my shot was even worse than the last one' (Khair, 2018: 64). When both The Thing about Thugs and Night of Happiness are read with a perspective of postcolonial understanding, it seems clear that colonized - or former colonized- subjects identify the colonizer culture with a symbol appropriate to their time; a god in 19th Century and a game in $21^{\text {st }}$ Century. As abovementioned, colonial discourse also expects the colonized to imitate the colonizer culture, traditions and habits to 'domesticate' the 'savage' colonized culture. However, this new social reproduction has never been fully accomplished and the colonized imitation is regarded as a fake, ineffective copy of the colonizer. Therefore, this mimicry has never been able to be far from mockery. It is just like a parody of the colonizer.

Anil Mehrotra thinks he has a consistent reality which is far from crisis until he accepts Ahmed's offer to go upstairs and taste their famous halva. That is the time when Anil loses the control of his reality. He feels as if he is in a different time and space. He describes his feelings by saying that 'I was stepping into another medium, a denser, slower one, something more resistant' (Khair, 2018: 24). The place is far from the comfort of his part of the society. In his postcolonial simulation, he feels happy since he creates a simulated identity in it. At first, pretending to eat the 'invisible halva' does not evoke existential questions in Anil's mind. He thinks it is shocking to see 
Ahmed in such an insane behaviour of eating halva that does not exist. Anil does not question the possibility of his insanity because he is sure of that. However, he is puzzled also about his identity as he gradually discovers the background of Ahmed. He starts to have problems in identifying Ahmed and says 'he was not a solid human being but something amorphous, imaginary, ghostly' (Khair, 2018: 115), but he eventually understands that it is not Ahmed but himself who is amorphous. Throughout the novel, it is Anil who discovers his own illusions by unfolding Ahmed's story. When he finds Ahmed's tiffin carrier with the smell of halva in his locked office room through the end of the novel, he begins to question his reality, and thinks the possibility of his insanity.

It is quite easy and comfortable for Anil to label Ahmed as an insane person or an Islamist terrorist. However, through the end of the novel, he realizes that it is really hard to decide what the truth is since he faces with the realities of his nation. His constructed world collapses and he cannot dare face the truth by opening the tiffin carrier. He confesses his doubts and fears at the end of the novel.

[...] what do I do with that tiffin carrier with the ghostly halwa? What happens when I open it for the missus -or for you- and you see nothing, you smell nothing. What happens to me then? Can I trust myself any longer?[...] I do not even dare open the tiffin carrier in front of you- or anyone else. I do not dare take the risk! (Khair, 2018: 152)

As it is mentioned before, Anil is unsure whether he or Ahmed has delusions. $\mathrm{He}$ is afraid of facing the situation and Khair leaves it without an answer at the end. It is never possible for Anil to find the truth in this case. What he defines as 'sensible' are all western perceptions and he cannot decide what sensible is when he faces with the realities of his nation.

Another important example of identity crisis in the novel is Roshni. She represents the other in the society. She is not accepted both by Muslims and Hindus. Everyone tries to define her in the novel but they are unable to do that. Roshni's inbetween character ends up with the tragic murder of her.

In Bhabha's own words; 'colonial discourse produces the colonized as a social reality which is at once an 'other' and yet entirely knowable and visible' (Bhabha, 1996: 71-72). However, it is really hard to identify Roshni as a social reality because nobody knows the origin of her in the novel. Her father is an unknown man and people cannot decide whether he is a Muslim, Hindu or a Buddhist. Since she is not 'entirely knowable and visible', there is a continuous effort in the novel to define her. The character stands for in-between postcolonial identity of the colonized. Just like the colonized cultures, she does not have much to put forward about her past, and it is not easy to identify her with a single name. Khair introduces Roshni by reflecting this identity confusion.

She was given a name, a Hindu one. But another man corrected the first one and gave another name, a Christian one this time. A third man offered a third name. She was a woman of various names. One of them was Roshni. (Khair, 2018: 100)

Roshni's tragic story begins when she and Ahmed decide to get married. Ahmed's Muslim community finds it hard to accept her although a marriage by a mullah is more than enough for Ahmed's mother. However, the community is not satisfied with 
this Islamic wedding because according to them, 'she doesn't look like a Muslim' (Khair, 2018: 112). It is not enough to declare an identity for Roshni unless her origin is known by others. She imitates her mother-in-law's dress code to be accepted in the community, but Ahmed objects to this situation since he thinks it is not a must for her to change what she really is. He says 'they will never accept you no matter what you do' (Khair, 2018: 113). However, the problem here is that Roshni is not sure about what she really is, and this makes her feel alienated. This sense of alienation is apparent when Roshni defends her imitation of Ahmed's mother by saying to her husband that 'I only want to be seen by you' (Khair, 2018: 113). Here, it is possible to say that Roshni is a true example of what immigrants feel in the West. In both Roshni's and immigrants' situations, the main problem is to be seen and accepted by the society

One of the most striking points is Roshni's murder in the novel. During the first years of her marriage, she tries hard to be accepted as a Muslim. However, Khair reveals that she is killed by Hindu fanatics in Gujarat Riots in 2002. Her murder is ironic since she is accused of being Muslim and, interestingly, her origin seems to be a source of confusion again. One of the men in the crowd shouts at her by defining her as a 'Pakistani whore'. The most striking point in this event is that Roshni does not object to these claims from the crowd. She does not say anything even while she is being burned. This indicates that Roshni now knows it is useless to try to persuade them or begging for their mercy. She is aware of her situation and simply gives up the idea of being accepted by them. She symbolically shares the same tragic end with many immigrants having problems in orientation and acceptance in the colonizer culture.

She did not even react when the South Indian man, in one last attempt to help her, screamed that she was not a Muslim. 'Look at her', he shouted, from his doorway, where the women held him back, 'Look at her. Does she look Muslim? But Roshni did not ply this sliver of doubt inserted in the mob by the old man. She did not claim she was not Muslim. She did not say anything. She neither cried nor remonstrated; she never pleaded. (Khair, 2018: 129)

The death of Roshni is a real trauma for Ahmed who also has serious identity problems. In the beginning of the novel, Ahmed is portrayed by Khair as a decent Muslim man who leads a modest life with his wife. However, as his story is revealed by the narrator, it is understood that Ahmed's life is also far from being simple. In this sense, Ahmed and Karim from Khair's another novel, How to Fight Islamist Terror from the Missionary Position which will be held in the next chapter, have the same qualities as the minority in the society. They both lead simple lives although they have unsolved problems which are not revealed to the other characters around them.

Ahmed is a character who is in between his religious background and the multicultural atmosphere of his country. He is grown up in a highly conservative Muslim community, but during his days as a tourist guide, he has the chance to interact with other cultures and religions. Ahmed begins to alienate from his 'mohalla', and he becomes the main source of discontent among the community members since he gives up Friday prayers and has Hindu and Buddhist friends. His disapproved marriage and the death of his mother cut the link between him and his community. He leaves his 
hometown and alienates from the rest of the society. He starts to live as an introvert, and does not share anything with the rest of the people around him. This alienation causes orientation problems again, and it makes Ahmed another 'other' in the novel.

Khair does not say much about Ahmed's reaction to Roshni's murder. The reader only knows that 'Ahmed claimed and buried her charred remains in a Muslim graveyard, three or four days later, when such things could be done' (Khair, 2018: 131). This indicates Ahmed's refusal of her death and his alienation turns into a complete isolation from the society. According to the reports Devi Prasad prepares for Anil, Ahmed continues to live a life as if he is still together with Roshni. It also may be seen as a reference to the colonized subjects' constructed reality. With a trauma of a loss, Ahmed creates a simulation for him to feel safe just like the colonized invents an identity to escape the tragedy of colonization. Khair proposes that both Ahmed and Anil live in their own invented lives although their purposes of inventing them are different.

It is the proof of Khair's talent that he creates an ironical duplicity in the novel. It is hard to decide whether Anil or Ahmed lives in an illusion. However, it is also apparent that both of them have serious problems with their sense of belonging. Anil has difficulties in defining himself as Hindu, and as it is mentioned before in this chapter, he does not have consistent knowledge about his country and culture. On the other hand, Ahmed and Roshni try hard to be accepted by the society, but they have the same difficulties with Anil in having a sense of belonging. These problems of identity lead the characters to alienate themselves from the reality, and Khair expresses this fact brilliantly in the novel by employing the symbol of 'invisible halwa'. The reader does not know for sure whether the halwa is invisible or it is Anil who cannot see the reality. It is nearly impossible to find out whose perception is deceptive. This dilemma is also valid in cultural relationships between the colonizer and the colonized since it is hard to say which perception is the reality. It is amorphous whether the colonized has the halwa or the colonizer fails to see it.

Another important symbol of identity crisis in the novel is 'the son of the nation' case. Khair portrays an author of Indian origin called the son of the nation although it is just his second trip to the country. Khair overtly criticizes the contemporary Indian origin writers. According to him, it is nonsense to be seen as the representative of Indian culture without fully understanding it as an Indian. Claiming to be a narrator of the culture with a western mind is deceptive for Khair. His witty and sarcastic narration shows itself again in this part.

This being only his second trip to the country, as the missus had informed me, he must have arrived on time, and was now waiting for the deputy minister and the senior writer to make their appearance. [...] The son of the nation still had to learn the national trick of arriving fashionably late, I thought. (Khair, 2018: 41)

Khair mocks with a new position in cultural identity creating 'homeless' postcolonial individuals who have problems in the sense of belonging both physically and culturally. They neither match the definition of 'the other' by colonial discourse nor see themselves as a part of the western world. 


\section{BIBLIOGRAPHY}

\section{Primary Sources}

BHABHA, Homi K, (1996), Locations of Culture: Discussing Post-Colonial Culture. London: Routledge.

Khair, Tabish, (2018), Night of Happiness. Pan Macmillan India.

MERCER, Kobena, (1995), 'Welcome to the Jungle: Identity and Diversity in Postmodern Politics', in Jonathan Rutherford (ed.), Identity: Community, Culture, Difference, London, Lawrence \& Wishart.

\section{Secondary Sources}

KHAIR, Tabish, (2005), Babu Fictions: Alienation in Contemporary Indian English Novels. Oxford University Press.

MONDAL, Anindita, (2014), "Postcolonial Theory: Bhabha and Fanon", International Journal of Science and Research (IJSR), Vol. 3, No. 11, 2965-2968.

SAID, Edward. W., (1978), Orientalism. New York: Pantheon Books.

WANG, Ning. (1997), "Orientalism versus Occidentalism?" New Literary History, Vol. 28 , No. 1, 57-67. 